\title{
The worked bone industry and intrusive fauna associated with the prehistoric cave burials of Abri des Autours (Belgium)
}

\author{
Quentin GOFFETTE \\ Royal Belgian Institute of Natural Sciences, \\ Vautierstraat 29, B-1000 Brussels (Belgium) \\ quentin.goffette@naturalsciences.be \\ Veerle ROTS \\ Archéologie préhistorique/Traceolab,
} Quai Roosevelt, 1B (Bât. A4), B-4000 Liège (Belgium)

Caroline POLET

Royal Belgian Institute of Natural Sciences, Vautierstraat 29, B-1000 Brussels (Belgium)

Nicolas CAUWE

Royal Museums of Art and History, Parc du Cinquantenaire 10, B-1000 Brussels (Belgium)

Richard SMITH

Royal Belgian Institute of Natural Sciences, Vautierstraat 29, B-1000 Brussels (Belgium)

Thierry SMITH

Royal Belgian Institute of Natural Sciences, Vautierstraat 29, B-1000 Brussels (Belgium)

Published on 29 December 2017

Goffette Q., Rots V., Polet C., Cauwe N., Smith R. \& Smith T. 2017. - The worked bone industry and intrusive fauna associated with the prehistoric cave burials of Abri des Autours (Belgium). Anthropozoologica 52 (2): 185-201. https:// doi.org/10.5252/az2017n2a4

\section{ABSTRACT}

The excavation of the Abri des Autours, a rock-shelter located in southern Belgium, enabled the discovery of three human burials, two dated to the Early Mesolithic and a third dated to the Middle Neolithic. In addition to the human bones, more than 200 faunal remains were uncovered. A taphonomic analysis was undertaken to determine whether their presence resulted from anthropogenic activities and whether they are linked to the burials. Two assemblages were distinguished. 


\section{KEY WORDS}

Belgium,

Early Mesolithic,

Middle Neolithic

bone industry,

burials,

cave,

funerary practices

taphonomy,

zooarchaeology

MOTS CLÉS

Belgique,

Mésolithique ancien,

Néolithique moyen,

industrie osseuse

sépultures

grotte,

pratiques funeraires,

taphonomie,

archéozoologie.
The majority of the fauna corresponds to remains of animals found scattered throughout the cave, including in the Mesolithic levels. These are mainly portions of carcasses brought in to the rockshelter by scavengers or predators. Therefore, their deposition did not result from human activity. Thus far, no animal bone had been found in direct association with Mesolithic burials in Belgium, and this site conforms to that pattern. Moreover, this interpretation corroborates the archaeological study, which did not uncover any traces of domestic activity in the cave, during either the Mesolithic or the Neolithic. On the other hand, several bone artefacts, including various tools and a pendant, were also identified. With the exception of an isolated artefact, all of these were clearly associated with the Middle Neolithic burial (Michelsberg culture). This is only the fourth Neolithic cave burial to have yielded animal bone artefacts in Belgium. A preliminary micro-wear analysis has confirmed that these objects had been used before being deposited and has allowed us to propose several hypotheses concerning their original use.

\section{RÉSUMÉ}

Industrie osseuse et faune intrusive dans les sépultures préhistoriques de l'Abri des Autours.

La fouille de l'Abri des Autours, un abri-sous-roche situé dans le sud de la Belgique, a permis la découverte de trois sépultures humaines, dont deux attribuées au Mésolithique ancien et une au Néolithique moyen. Outre les ossements humains, plus de 200 restes fauniques ont été mis au jour. Une analyse taphonomique a été entreprise afin de déterminer si leur présence résulte d'activités anthropiques et s'ils sont liés aux sépultures. Deux ensembles ont ainsi été distingués. La majorité de la faune correspond en réalité à des restes d'animaux retrouvés éparpillés dans la grotte, y compris dans les niveaux mésolithiques. Il s'agit principalement d'éléments de carcasses d'animaux apportés dans l'abri-sous-roche par des animaux charognards ou prédateurs. Leur dépôt ne résulte donc pas d'activités humaines. Jusqu'à présent, aucun reste animal n'a été retrouvé en association directe avec des sépultures mésolithiques en Belgique, ce que ce site confirme. Par ailleurs, cette interprétation corrobore l'étude archéologique qui n’a pas mis en évidence de témoins d'activités domestiques dans la grotte, que ce soit pour le Mésolithique ou le Néolithique. D’autre part, plusieurs objets en matière animale comprenant divers outils et un pendentif ont été identifiés. À l'exception d'un artefact hors contexte, tous étaient clairement associés à la sépulture du Néolithique moyen (culture Michelsberg). Ce n'est que la quatrième sépulture néolithique en grotte ayant livré des dépôts d'artefacts en matière animale en Belgique. Une étude tracéologique préliminaire a confirmé que ces objets avaient été utilisés avant leur dépôt et a permis de proposer quelques hypothèses quant à leur utilisation originelle.

\section{INTRODUCTION}

Prehistoric human burials have been discovered in several caves and rock-shelters in the southern part of Belgium (Wallonia) starting as early as the beginning of the $19^{\text {th }}$ century. The Meuse Basin and its karstic environment played a prominent role in the past by providing a significant number of cavities, which prehistoric humans used for a variety of purposes from prehistory right through to the Modern period. Most of the burials uncovered in caves were initially attributed to the Neolithic (6 $6^{\text {th }}$ to $3^{\text {rd }}$ millennium BC), but in the 1980 s, the proliferation of radiocarbon dating eventually documented the presence of Mesolithic (10 $10^{\text {th }}$ to $6^{\text {th }}$ millennium BC) burials as well (Toussaint 2010).

During the past twenty-five years, prehistoric burials have received increased attention, and complementary human osteology analysis and radiocarbon dating have been performed on them. In the wake of those new investigations, reviews were published of both the Mesolithic (Toussaint 2010) and the Neolithic (Cauwe 2004) cave burials from the Meuse Basin.

The excavation of the Abri des Autours, a rock-shelter located in southern Belgium, enabled the discovery of three human burials, two dated to the Early Mesolithic and a third, collec- tive burial dated to the Middle Neolithic (Michelsberg culture). In addition to the human bones, more than 200 faunal remains were uncovered. Although the human remains from Abri des Autours were included in these reviews, no attention has yet been paid to the faunal remains, even though they could potentially contribute valuable information on several aspects of human practices.

The animal remains recovered from Abri des Autours include several items that have been modified into artefacts; the majority, however, have not been worked. All but one of the bone artefacts were found within the Neolithic collective burial; the exception is one isolated element that could be Mesolithic in age. Because faunal deposits in Neolithic burial contexts are rare in Belgium, the study and publication of the material recovered within the Michelsberg collective burial of Abri des Autours could expand our knowledge about funerary practices. With this in mind, we tried to identify the raw material those bone artefacts were made of, whether they saw any use before they were placed with the burial, and if so, what they had been used for.

The unworked bone was discovered scattered throughout the cave, and mostly not in close association with either the Mesolithic or the Neolithic burials. Therefore their chrono- 


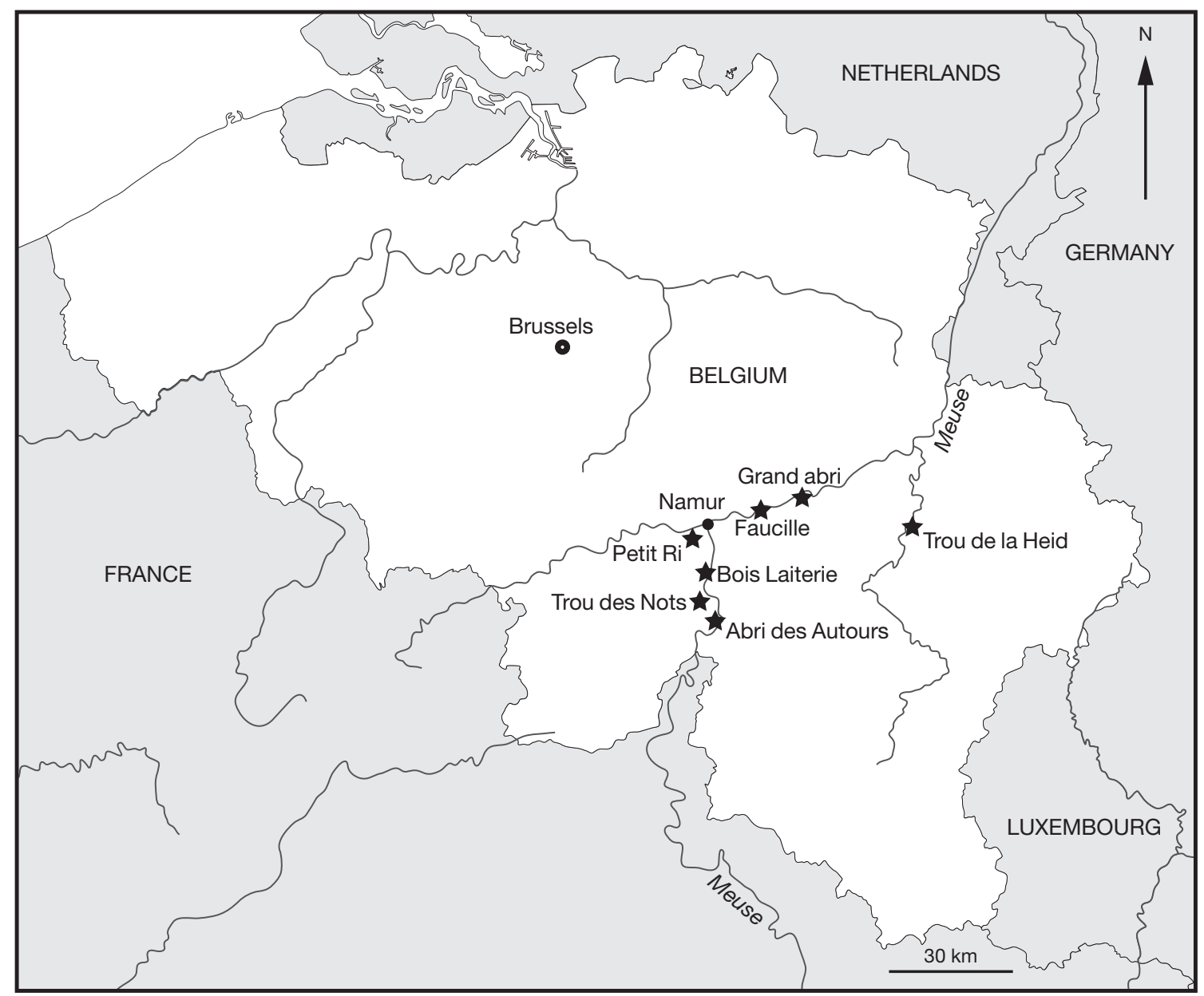

FIG. 1. - Location of Abri des Autours and other Belgian sites mentioned in the text.

logical attribution is unclear. However, two unworked bones were mixed with the human remains of the Neolithic collective burial. Some of the other unworked bones were discovered close to or mixed with Mesolithic human remains of the collective burial (see below). The question arose whether this faunal assemblage resulted from Mesolithic human activities, and what the nature of those activities could have been - either ritual activities linked to the burials, or domestic activities.

In this context, we note that M. Toussaint (2010) highlighted 'future prospects' for the study of the Mesolithic period, including the study of past diet through stable isotopic analysis. Such analysis has already yielded valuable results on Mesolithic and Neolithic human remains from the Meuse Basin (Bocherens et al. 2007). The results highlight that the hunting of terrestrial mammals was of major importance during the Mesolithic (first half of the $10^{\text {th }}$ millennium BC to end of the $9^{\text {th }}$ millennium BC), while freshwater foods seem to have been of limited importance in terms of the protein component of the human diet. In contrast, during the Middle Neolithic (c. 4300-3000 BC), the reliance on aquatic resources increased.

Reconstructions of past diet rely not only on biochemical analyses, but also on studies of the faunal remains accumulated by humans. We felt that the faunal remains from $\mathrm{Abri}$ des Autours were worth investigating, since they could add to our understanding of Mesolithic past diet. Even though no domestic activities were detected during the excavation and subsequent archaeological study of the site (Cauwe 1995), that does not exclude the possibility that some of the scattered faunal remains could be the result of domestic activities that took place during the Mesolithic, the Neolithic or more recent periods. To disentangle this assemblage of scattered bones, we performed zooarchaeological identification and an in-depth taphonomic study.

\section{LOCATION OF ABRI DES AUTOURS AND DESCRIPTION OF THE BURIALS}

Abri des Autours (tr. Autours rock-shelter, 'autour' meaning 'goshawk' Accipiter gentilis (Linnaeus, 1758)) is located in the southern part of Belgium, about $4 \mathrm{~km}$ south-west of the modern town of Dinant (Fig. 1). It extends into the Freyr cliff, a Tournaisian (early Carboniferous) limestone massif on the right bank of the river Meuse. The rock-shelter faces north-west, and today the entrance is off a rocky overhang overlooking the water $c .90$ metres below. It is approximately 


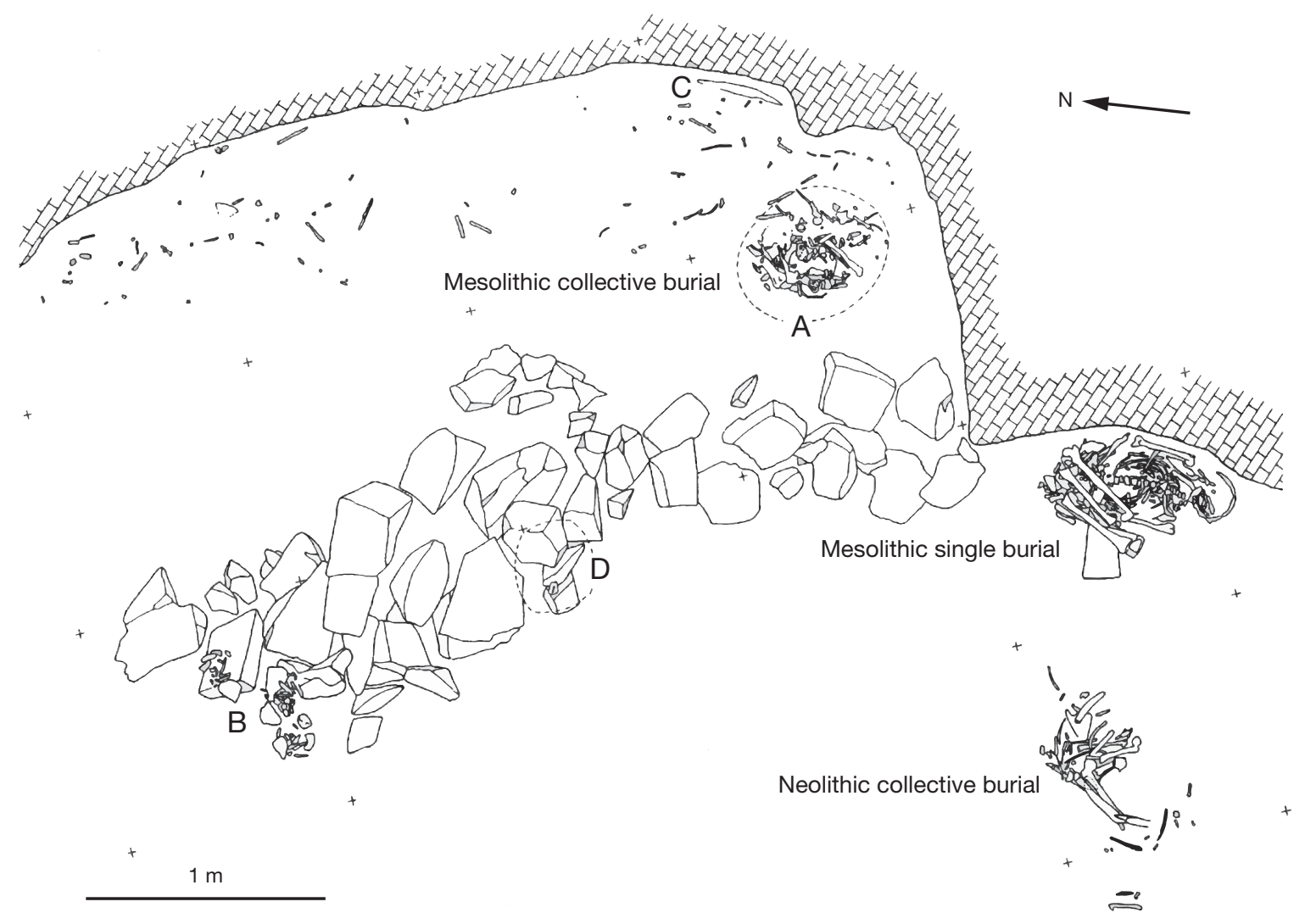

FIG. 2. - Plan of Abri des Autours: A, circular depression; B, rubble of old (unpublished) excavations; C, crack in the rock; D, pit under low wall (from Polet \& Cauwe 2007).

triangular in shape and measures $c .20 \mathrm{~m}$ in breadth and $6 \mathrm{~m}$ in depth. Before the most recent excavations, in 1992 and 1993, it measured $3 \mathrm{~m}$ in height at the centre of the opening (Fig. 2). The ground slopes down from the south-east to the north-west.

Some time prior to 1992, the Abri des Autours was partly excavated by persons unknown, who never published the results of their fieldwork (Cauwe 1994). Those excavations disturbed the prehistoric burials and brought human bones to the surface, that were left on the site by the excavators and (re-)discovered during more recent archaeological prospection. In order to properly document the human activities that took place in the rock-shelter, new excavations were undertaken by one of us, Nicolas Cauwe, in 1992 and 1993.

The cavity of the rock shelter had become partly filled in with sediments coming from the plateau located above, from Holocene colluviums and a large amount of cryoclastic activity, which resulted in a complex stratigraphy (Fig. 3). The old excavations further complicated the picture.

The following details on the three prehistoric burials are taken from Cauwe (1995), Polet \& Cauwe (2007) and Polet \& Dutour (2007):

The Neolithic collective burial was located in the southeastern part of the cavity, $1 \mathrm{~m}$ inside from the entrance. It contained the bones of at least six children and three adults, associated with two lithic tools (a scraper and a retouched blade); a few ceramic potsherds; two nacre beads; and a total of nine mammal remains. The latter comprised six tools, and two fragments showing no traces of human modification (see below, part "Animal remains from the Neolithic burial without anthropogenic modifications"). Some anatomical links were detected between the human bones, but most of them had been manipulated and were no longer in articulation, suggesting that this area was used as a secondary burial area for body parts that had initially been deposited elsewhere. Alternatively, it may have been a place for successive body depositions, involving partial removal of previously deposited bones (Polet \& Cauwe 2007). The archaeological artefacts allow for an attribution to the Michelsberg, which was confirmed by a radiocarbon date of $4224-4040 \mathrm{cal}$. BC at 1 sigma obtained on human bone (OxA-5837, $5300 \pm$ 55 BP) (Cauwe 1995).

The Mesolithic collective burial was found at the back of the rock-shelter, behind a low, artificial wall constructed of unworked stone blocks, oriented south-east-north-west, dividing the cavity in two (Figs 2; 3[9]). Some of the bones were deposited, but not buried, in a small pit (with a diameter of $1 \mathrm{~m}$ ) that had been dug out along the natural rear wall of the cavity. The human osteology analysis highlighted that the bodies were disarticulated and that they had been sorted. The hand and foot bones had been placed in a small, natural crack in the natural rear wall, and a fragment of a human skull had been intentionally buried under the low artificial wall. Other human bones were scattered over the surface north of 


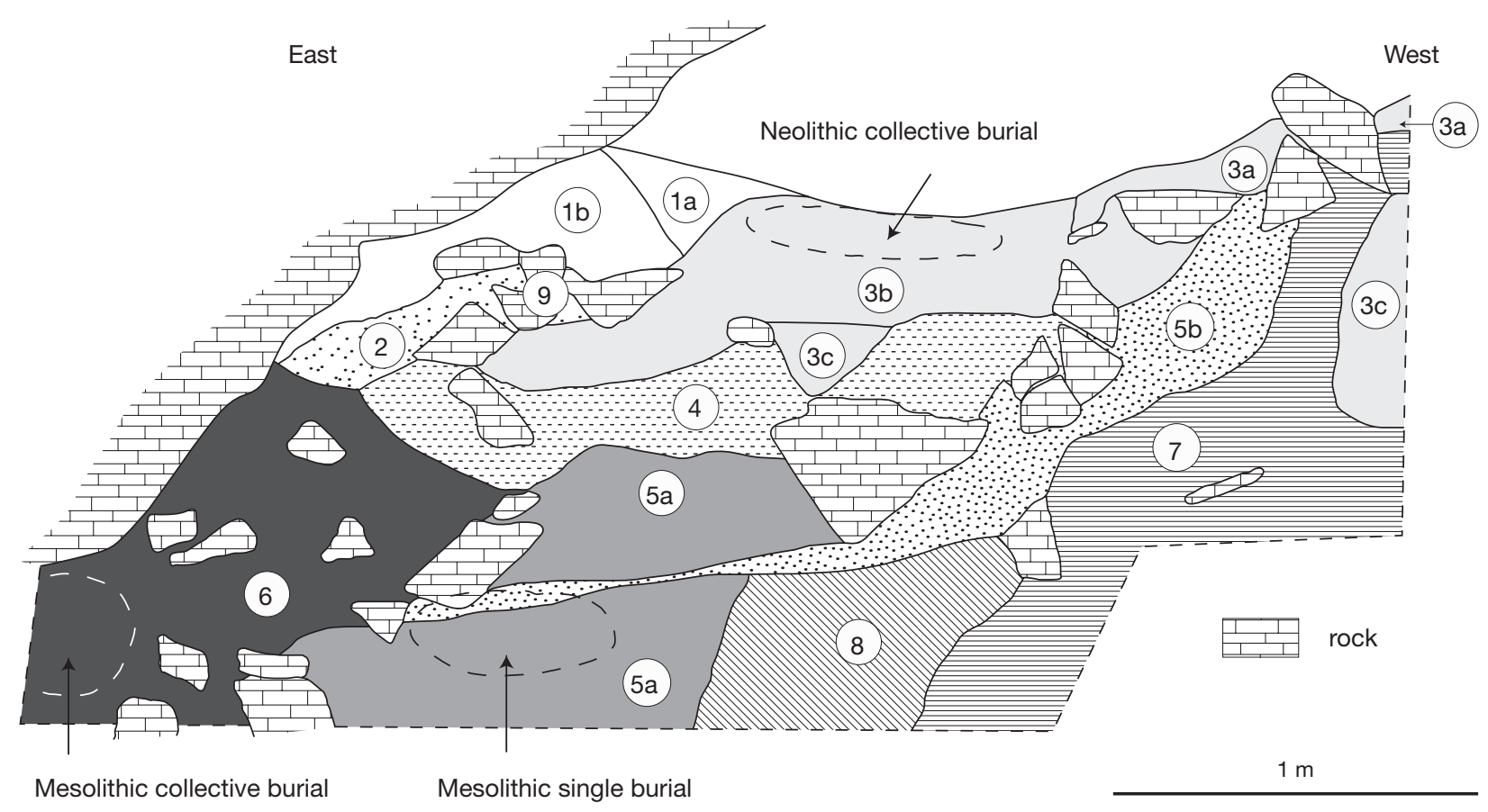

FIG. 3. - Stratigraphy of Abri des Autours, east-west profile (modified from Cauwe 1994): 1a, b, clay, without pebbles; 2 , as layer 6, but with more clay; 3a, brown, argillaceous deposit with small, densely dispersed pebbles; $\mathbf{3 b}$, as layer $3 \mathbf{a}$, but less humic. Contains the Neolithic multiple burial; $\mathbf{3 c}$, as layer $3 a$, but strongly compacted by calcite precipitations; $\mathbf{4}$, clay with fine pebbles; $\mathbf{5 a}, \mathbf{b}$, cryoclastic deposit without humic or clayish fraction; layer $5 \mathrm{~b}$ corresponds to very fine gravels, while layer 5 a includes larger elements. The Mesolithic single burial extends through both of these layers; 6 , brown-grey clayey deposit, strongly inclined. Contains the Mesolithic collective burial; 7, cryoclastic layer, included in clayey orange-brown sediment; 8, thin pebble deposit mixed with greyish sediment; 9, low wall constructed of unworked stone blocks.

the actual burial. In total, the bones of at least six children and six adults were recovered. One of these individuals had been cremated. The individuals had been treated differently: the bones of some were interred to start with, but then were deliberately scattered afterwards, whereas those of others, such as the cremated individual, were perhaps immediately scattered over the funeral space (Cauwe 2001). Some of the bones display gnaw marks made by rodents, indicating that they remained exposed at the surface for an unknown period of time (Polet \& Cauwe 2007). Some non-bone archaeological material, consisting of four non-retouched flint bladelets, was mixed with the human remains. Those bladelets were attributed to the Mesolithic period based on their morphology. A radiocarbon date obtained on human bone provided an age of 8332-7996 cal. BC at 1 sigma (OxA-5838, $9090 \pm$ 140 BP) (Cauwe 1995).

The Mesolithic single burial was located in the southern part of the cavity, in front of the artificial stone wall, at approximately $2 \mathrm{~m}$ distance from the entrance. It contained a single, almost complete skeleton still in anatomical position, most probably of a woman more than 50 years of age. She had been placed on her back with her head pointing toward the west. No grave goods were associated with the burial, but a small flagstone had been placed behind the tibiae. The body had been covered with ochre at the level of the pelvis. Lesions detected on her skeleton include a complete fracture of the two forearms and of the proximal epiphysis of the left tibia. Together with the vertebral compressions that were observed, these may have resulted from a single, brutal accident. The healing process of the bone lesions indicates that the woman survived this accident. A radiocarbon date of 8912-8428 cal. BC at 1 sigma obtained on human bone (0xA-4917, $9500 \pm 75$ BP) (Cauwe 1995) makes the Mesolithic single burial chronologically the oldest to have been placed in the Abri des Autours.

\section{METHOD}

The site has been the subject of several publications focusing mainly on the funerary aspects (for a detailed list of publications, see Cauwe 1995, 1997) and the human remains (Polet \& Cauwe 2007; Polet \& Dutour 2007). Some of the bone artefacts were listed by Sidéra (2000), but none of them were depicted.

In order to publish the faunal assemblage, we verified the earlier identifications and we checked the human remains from the rock-shelter. While doing this, we found several other animal bone fragments which had originally been mixed with those human bones.

The zooarchaeological analysis consisted of two distinct aspects. On the one hand, a zooarchaeological study, including a taphonomic analysis, was performed on the scattered bones collected within the cavity. Specifically, we analyzed the faunal spectrum (taxonomic diversity, biotopes, domestic or wild status, size of the species present) and we looked for the presence of taphonomic evidence (anthropogenic marks, gnaw marks from animals, fragmentation, patina). 
TABLE 1. - Taxonomic identifications of the scattered faunal remains from Abri des Autours. Abbreviations: NISP, number of identified specimens; MNI, minimum number of individuals.

NISP MNI

Gastropods
Grove/White-lipped snail (Cepaea nemoralis (Linnaeus,
1758)/Cepaea hortensis (O.F. Müller, 1774))
Glass snail (Oxychilus sp.)

Amphibians

Common toad (Bufo bufo (Linnaeus, 1758))

Toad (Bufo sp.)

11

\section{Birds}

Black grouse (Lyrurus tetrix (Linnaeus, 1758))

Grey partridge (Perdix perdix (Linnaeus, 1758))

Grey partridge? (cf. Perdix perdix)

Tawny owl (Strix aluco Linnaeus, 1758)

Wood pigeon (Columba palumbus Linnaeus, 1758)

Thrush size of common blackbird (cf. Turdus merula

Linnaeus, 1758)

Thrush size of song thrush (cf. Turdus philomelos

Brehm, 1831)

Common raven (Corvus corax Linnaeus, 1758)

\section{Wild mammals}

European mole (Talpa europaea Linnaeus, 1758)

Beech/European pine marten (Martes foina (Erxleben, 1777)/Martes martes (Linnaeus, 1758))

Wild/domestic cat (Felis silvestris Schreber, 1775/Felis catus Linnaeus, 1758)

Arctic fox (Vulpes lagopus Linnaeus, 1758)

Red fox (Vulpes vulpes (Linnaeus, 1758))

Arctic/red fox (Vulpes lagopus/Vulpes vulpes)

Field mouse (Apodemus sp.)

European water vole (Arvicola amphibius (Linnaeus, 1758))

Field vole (Microtus agrestis (Linnaeus, 1761))

Bank vole (Myodes glareolus (Schreber, 1780))

European hare (Lepus europaeus Pallas, 1778)

Wild boar (Sus scrofa Linnaeus, 1758)

Wild boar/domestic pig (Sus scrofa/Sus domesticus

Erxleben, 1777)

Roe deer (Capreolus capreolus (Linnaeus, 1758))

Red deer (Cervus elaphus Linnaeus, 1758)

\section{Domestic mammals}

Rabbit (Oryctolagus cuniculus (Linnaeus, 1758))

Rabbit? (cf. Oryctolagus cuniculus)

Cattle (Bos taurus Bojanus, 1827)

Cattle? (cf. Bos taurus)

Dog (Canis familiaris Linnaeus, 1758)

Goat (Capra hircus Erxleben, 1777)

Sheep (Ovis aries Linnaeus, 1758)

Sheep/goat (Ovis aries/Capra hircus) (including 22 bones from 1 individual)

Total identified fragments

Ruminant size of sheep

Unidentified mammal size of cattle/deer

Unidentified mammal size of sheep/pig

Unidentified mammal

Total unidentified fragments

Total

$\begin{array}{ll}1 & 1 \\ 3 & -\end{array}$

$3-$

11

11

$1-$

$3-$

$\begin{array}{ll}3 & - \\ 1 & 1\end{array}$

52

52

21

11

11

22

41

72

$8-$

21

21

11

$\begin{array}{rr}1 & 1 \\ 18 & 3\end{array}$

18
4

336

41

11

9

2 -

11

1 -

11

11

21

$33-$

$164 \quad 41$

$6-$

$4-$

$22-$

$32-$

$64-$

$228 \quad 41$

On the other hand, we examined the animal remains and the bone industry directly associated with the Michelsberg collective burial in order to identify the species and elements from which the bone artefacts had been made, determine if the tools had been used, through a preliminary micro-wear analysis, and verify the presence of macro residues associated with the (presumed Mesolithic) ornament that might indicate how it had been suspended.

Animal bones were recovered by hand and by dry sieving through a mesh with an aperture of $5 \mathrm{~mm}$. The depth and the location of the archaeological finds, including the bone material, were recorded using a $1 \times 1 \mathrm{~m}$ grid, and each piece was plotted on the excavation plan. However, some provenance information had been lost since the time of the excavation, which made it impossible to determine the position of all of the faunal remains. Below, we provide separate discussions of the scattered bones which could not be directly associated with any particular structure (part "Analysis of the scattered animal bones"), the bones discovered within the Neolithic burial but with no anthropogenic modification (part "Animal remains from the Neolithic burial without anthropogenic modifications"), and the bone artefacts (part "Analysis of the bone industry").

The faunal material was identified by comparison with the recent skeletal collections of the Royal Belgian Institute of Natural Sciences (RBINS) and with the help of classic reference publications.

Both the preliminary micro-wear analysis and the residue analysis (see part "Analysis of the bone industry") were performed at TraceoLab, Liège University (ULg, Belgium). The micro-wear analysis was performed using a binocular stereomicroscope (Olympus, magnification up to 56x), a Zeiss Axio V16 microscope (magnification up to $180 \times$ ) and an Olympus reflected-light metallurgical microscope (magnification up to 1000x). Images were taken with a Zeiss AxioCam ICc5 and an Olympus SC100 camera. For the residue analysis, pipette extractions were performed with demineralised water. The solutions were transferred to glass slides and examined under a Zeiss AxioScope A1 microscope equipped with transmitted light, polarization and Differential interference contrast. Pictures were taken with a Zeiss AxioCam ICc5 camera.

\section{ANALYSIS OF THE SCATTERED ANIMAL BONES}

Excluding the items relating to the bone industry, a total of 228 (NISP) faunal remains were recovered, representing 36 taxa, 22 of which were identified to the species level (Table 1). Only 64 fragments remained unidentified. Two gastropod species and one amphibian, the common toad Bufo bufo (Linnaeus, 1758) are present. Among the birds, only wild species were identified. Most of them are song birds, namely, thrushes Turdus sp. and common raven Corvus corax Linnaeus, 1758. Other species are black grouse Lyrurus tetrix (Linnaeus, 1758), grey partridge Perdix perdix (Linnaeus, 1758), tawny owl Strix aluco Linnaeus, 1758, and wood pigeon Columba palumbus Linnaeus, 1758. All the birds were adults, and the remains of each of the taxa may derive from a single individual, with the exception of the thrushes, of which at least four individuals are present.

The remains of both domestic and wild mammals were identified. The domestic species include rabbit Oryctolagus cuniculus (Linnaeus, 1758), cattle Bos taurus Bojanus, 1827, dog Canis familiaris Linnaeus, 1758, sheep Ovis aries Linnaeus, 1758, and goat Capra hircus Erxleben, 1777, all possibly belonging 
TABLE 2. - Measurements (in mm) of two bones from the Abri des Autours identified as arctic fox Vulpes lagopus Linnaeus, 1758, compared with published measurements of arctic and red fox Vulpes vulpes (Linnaeus, 1758) (Germonpré \& Sablin 2004). Measuring distances and their abbreviations follow Von den Driesch (1976). Abbreviations: Bd, Breadth of the distal end; Bp, Breadth of the proximal end; Dd, Depth of the distal end; Dp, Depth of the proximal end; GL, Greatest length; SD, Smallest breadth of the diaphysis.

\begin{tabular}{lccr}
\hline & Abri des Autours & Vulpes vulpes (Linnaeus, 1758) & Vulpes lagopus Linnaeus, 1758 \\
\hline Humerus & - & (Late glacial and recent-Belgium) & (Late glacial and recent-Belgium) \\
SD & 6,4 & $7.2-9.3(\mathrm{n}=37)$ & $5.9-7.3(\mathrm{n}=47)$ \\
Bd & 17,6 & $20.0-24.8(\mathrm{n}=32)$ & $15.8-18.9(\mathrm{n}=43)$ \\
Dd & 13,5 & $14.5-17.9(\mathrm{n}=19)$ & $11.6-14.6(\mathrm{n}=34)$ \\
\hline Metacarpus 5 & - & (Late glacial-Belgium) & $($ Late glacial-Belgium) \\
GL & 37,4 & $40.1-43.7(\mathrm{n}=3)$ & $32.2-36.6(\mathrm{n}=10)$ \\
Bp & 6,7 & $7.1-7.7(\mathrm{n}=3)$ & $5.6-6.9(\mathrm{n}=10)$ \\
Dp & 5,8 & $6.3-6.8(\mathrm{n}=3)$ & $5.3-5.8(\mathrm{n}=10)$ \\
Bd & 6,0 & $6.7-7.4(\mathrm{n}=4)$ & $5.3-6.4(\mathrm{n}=11)$ \\
Dd & 5,4 & $5.1-6.2(\mathrm{n}=3)$ & $4.7-5.5(\mathrm{n}=10)$
\end{tabular}

to one individual each except for rabbit, of which at least two adults or subadults and one perinatal were recognized. The wild or domestic status of some animals is uncertain. This is the case for the wild cat Felis silvestris Schreber, 1775 or the domestic cat Felis catus Linnaeus, 1758, and for the wild boar Sus scrofa Linnaeus, 1758 or the domestic pig Sus domesticus Erxleben, 1777.

The wild species include four rodent taxa, as well as mole Talpa europaea Linnaeus, 1758, marten Martes sp., arctic fox Vulpes lagopus Linnaeus, 1758, red fox Vulpes vulpes (Linnaeus, 1758), European hare Lepus europaeus Pallas, 1778 and larger mammals, such as roe deer Capreolus capreolus Linnaeus, 1758, red deer Cervus elaphus Linnaeus, 1758 and wild boar. Arctic and red fox can be distinguished on the basis of measurements (e. g., Germonpré \& Sablin 2004; Monchot \& Gendron 2010). The majority of the fox bones from the Abri des Autours come from immature individuals and therefore are not fully grown, which precludes assigning them to species on the basis of osteometry. However, four bones could be identified as arctic fox on the basis of osteometry. A complete fifth metacarpus and a distal humerus had their distal epiphysis fused and could therefore be measured. Compared with published data (Germonpré \& Sablin 2004), their dimensions fall outside the variation of modern or fossil red fox. The measurements of the humerus fall inside the variation of arctic fox, but in the case of the fifth metacarpus, the greatest length slightly exceeds $(0.8 \mathrm{~mm})$ the largest published dimensions for arctic fox (Table 2). As the other measurements of the metacarpus match arctic fox, we assume this metacarpus also comes from this species. Additionally, a mandible and an ulna, both complete, were assigned to arctic fox through comparison with recent material as no significant measurements could be taken. The permanent second molar is fully grown but unworn, and the third molar was lost during the life of the animal, allowing the dental alveolus to be filled in with bone tissue. The proximal epiphysis of the ulna is fused, but the distal epiphysis is still unfused. Despite their immature state, seven fox elements appear too large to pertain to arctic fox and are identified as red fox, while the remaining fox bones could not be identified to the species level. In total, at least one subadult arctic and red fox and one very young red fox are present.
Most of the suid remains also come from young animals and could therefore not be assigned further, to domestic pig or wild boar. However, fragments of two metacarpals and two phalanges were larger than any of the wild boars in the reference collection and were therefore identified as wild boar. Apart from this subadult or adult wild boar, at least one subadult, four juvenile and one perinatal suid were recognized.

The other remains may belong to a single individual each, except in the case of hare and (wild) cat. At least three adult/ subadult hares and one adult and one subadult domestic or wild cat are present.

\section{THE FAUNAL SPECTRUM AND ITS ENVIRONMENTAL AND CHRONOLOGICAL IMPLICATIONS}

The majority of the species identified are typical of a temperate climate and are likely to be Holocene in age. Only the arctic fox is typical of a glacial environment. This species was widespread in Europe during the last glaciation (Weichselian), until the Late Glacial. However, from the onset of the Holocene onward, the species is only present at sites situated within its modern distribution area (Sommer \& Benecke 2005), which excludes Belgium. The arctic fox thus must have been absent from our region during the Mesolithic, and the remains from the Abri des Autours must therefore pre-date the Mesolithic. There is no indication of human occupation inside the shelter during the Palaeolithic, but a Magdalenian backed bladelet was found on a slope formed by colluvia, just in front of the cavity. Because it lacks stratigraphic context, this bladelet cannot be used to argue for a Late Upper Palaeolithic presence in the vicinity of the rock-shelter. Consequently, we suggest that the bones of arctic fox represent an animal that died of natural causes. The rock-shelter was probably attractive to this species, which lives in dens and may have sheltered or bred there (Ginsberg \& Macdonald 1990).

The black grouse is a boreal-alpine species still living in Belgium today, although it is close to extinction. Today, it is restricted to the High Fence plateau, but it was formerly more widespread (Jacob et al. 2010). It was present until the late 1980s on the Croix-Scaille plateau, a forested massif situated 
about 30 kilometres to the south of Dinant (Ruwet 1988). Therefore, the presence of this species in the assemblage is not indicative of a particular chronological period.

By contrast, the domestic species are clear chronological indicators, since the timing of their domestication and arrival in our region is generally well documented. The dog was domesticated in Europe certainly by c. 15000 BC (Larson et al. 2012) but possibly as early as c. $30000 \mathrm{BC}$ (Germonpré et al. 2012). Consequently, the dog bones discovered could be Magdalenian in age or younger. Sheep, goat and cattle were absent from our region before the second half of the $6^{\text {th }}$ millennium $\mathrm{BC}$ for the Middle Plateau of Belgium and some centuries later for the rest of the country (e.g., Cordy \& Stassart 1984; Hachem 2001). The remains of sheep, goat and cattle recovered in the Abri des Autours must therefore date to the Neolithic or later. Indeed, historical documents indicate that during the $19^{\text {th }}$ century and continuing until the middle of the $20^{\text {th }}$ century, the cliffs of Freyr were much less wooded and that herds of sheep and goat were brought there for grazing. Finally, considering that the rabbit was introduced as a domestic species by the Late Medieval period (Ervynck et al. 1999), the rabbit bones must come from animals living in the area during the past 700 years. Due to the burrowing activities of the species, rabbit bones are frequently found in older deposits, where animals may have died of natural causes. The rabbit remains found in the layers of the Abri des Autours contain bones of very young individuals, which is consistent with such a natural death within a burrow. Such burrows were identified during the excavation.

\section{TAPHONOMIC ANALYSIS}

The scattered faunal remains show clear differences in colour and surface preservation. Unfortunately, these differences do not help with chronological attribution of the specimens because bones from very distinct time periods (e.g., arctic fox and goat) are similar in appearance at this site. Dissolution by plant roots accounts for some damage visible on most of the bones, but apart from this, while certain bones are strikingly worn, others are in a very good state of preservation. These differences in preservation suggest that different taphonomic processes operated before the bones were embedded in the sediment, and they strengthen the hypothesis of chronological heterogeneity evidenced by the taxonomic spectrum, which ranges from at least the Upper Palaeolithic to the Medieval period.

Careful examination under a binocular microscope (magnification $6.5-50 \times$ ) allowed for the detection of butchery marks on two articular portions of ribs of either sheep or goat. Both display chop marks, and one also has cut marks on the internal surface of the shaft. The profound, clean, acute ' $V$ ' crosssection of the cut mark, together with the heavy chop marks, indicate that they were left by metal tools (Greenfield 2006). Consequently, these bones must have been deposited at a time when metal butchery tools were in use, so after the Neolithic.

In general, the fragmentation rate is low, and the assemblage is dominated by (almost) complete bones, some with damaged extremities, and by large fragments. Post-depositional fragmentation is rare. This low fragmentation rate accounts for the high identification rate of the material. A distal humerus of a goat shows a helical fracture, indicating that it was broken when it was fresh (Outram 2002). Distal humeri with similar fractures are frequent in human settlements. Therefore, this breakage pattern could reflect butchery practices, although an accidental fracture cannot be ruled out. Because goat was introduced in north-western Europe during the Neolithic, this bone cannot pre-date this period, but it could be much younger, as it was found among the rubble of the old excavations.

Two bones show traces of burning, namely, a portion of a costal blade from a mammal of the size of the sheep, which was brown-grey in colour, and a phalanx 1 (proximal) of pig/ wild boar, which was blue-grey. No hearth was found at the level of the prehistoric deposits, whereas some hearths were present in the modern layers, the cavity having been used by campers as shelter. Therefore, the burned fragments are more likely to be recent intrusions.

In contrast, one in six faunal remains show traces of gnawing resulting from the action of animals, mostly carnivores (NISP: 26), but also rodents (NISP: 6). Rodent tooth impressions were found on bones of suids (5) and sheep or goat (1). These animals may have been consumed by humans and later gnawed by rodents. Gnaw marks made by carnivores - either predators or scavengers - are not present on specific skeletal elements but were mainly found on bones from small or medium-sized animals: sheep or goat (9), suid (7), hare (6), cattle (1), red fox (1), raven (1) and a mammal in the size range of sheep (1). Carnivore traces can be left on a bone either during the catching, killing or consumption of prey or during scavenging activities. In the former instances, the bone should be considered intrusive (sensu Gautier 1987) and not the result of human activities, while in the latter instance the animal it belonged to may have been consumed by humans, subsequently discarded by humans, and then gnawed by scavengers.

The species spectrum includes mostly small and mediumsized mammals. Those species may have been brought in to the rock-shelter by predators or scavengers, such as foxes, dogs and cats, whose bones have also been identified. Large mammals, such as the cattle and deer, which are less likely to be dragged by medium-sized scavengers, are not frequent and are mainly represented by small bones, such as phalanges. Some of the bones present may also result from natural deaths of organisms living there or taking advantage of the cavity for shelter or breeding. The latter explanation probably pertains to the toad, arctic fox, red fox and rabbit remains, and fits with the presence of very young animals. The bones of these animals are generally (almost) complete, which also suggests that they are elements of carcasses rather than human food refuse.

The common raven, which possibly nested locally on the cliffs of Freyr, may have been attracted by the leftovers of carcasses brought in to the rock-shelter by other animals (not humans), or it may even have been responsible for the accumulation of some of the bones.

No anatomical connections were detected among the animal remains during excavation, and no complete skeleton could be reconstructed. Most of the bones were scattered. However, bones of sheep or goat, i.e. coxal bones, several vertebrae and costae, discovered close to each other, likely represent the axial 
skeleton of one carcass that was likely brought in to the rockshelter by a carnivore, as no anthropic traces were found on these bones, while gnaw marks were numerous.

\section{CHARACTERIZATION OF THE ASSEMBLAGE}

Considering the near absence of anthropic traces on the scattered animal remains, as well as the high frequency of gnaw marks from carnivores, we would argue that the majority of the bones are not associated with the Mesolithic and Neolithic burials, but, rather, are intrusive, either representing parts of carcasses from animals which frequented the rock-shelter and died there or parts of carcasses brought in by scavengers or predators.

The few faunal remains that do display anthropogenic traces have been shown to be younger in age than the Mesolithic period; therefore, no non-human bone can be associated with Mesolithic burial or domestic activities. The only bone which could have resulted from Neolithic domestic activities is a goat humerus broken while fresh, the breakage pattern of which is reminiscent of butchery treatment. In order to rule out or confirm an attribution to the Neolithic and the hypothesis of domestic activity at that time, radiocarbon dating could be considered.

For now, the faunal analysis does not provide any irrefutable evidence of domestic activities or funerary practices associated with the prehistoric burials, thereby corroborating the conclusions of the archaeological study.

\section{ANIMAL REMAINS FROM THE NEOLITHIC BURIAL WITHOUT ANTHROPOGENIC MODIFICATIONS}

During excavation, two faunal items were found mixed with the human remains of the Neolithic collective burial. They show no traces of human modification and represent either unmodified portions of a larger artefact or wholly unmodified animal bone fragments.

The first of these specimens is an inferior left canine of a male suid, the proximal extremity of which is broken (Fig. 4A). If it is an artefact, it could be either a tool or an ornament. In the latter case, one would expect to find a suspension hole, which probably would have been situated on the missing proximal part. Both utilizations in a burial context are attested to during prehistory. Suid canines pierced to serve as ornaments are common in Europe from the early Neolithic onward (Barge-Mahieu 1991). Some micro scratches are visible on the tooth enamel, but it was impossible to determine whether they result from its use as tool, which has been frequently evidenced for Neolithic suid teeth, or from natural events occurring during the life of the animal. Unmodified suid canines are known from within funerary deposits of the Cerny group (Middle Neolithic), e.g., at the site of Passy, France (Sidéra 1997).

The second specimen is a distal fragment of medial or lateral half of a roe deer metatarsal with an unfused distal epiphysis (Fig. 4D), indicating that it comes from a young individual less than one-and-a-half years of age (Tomé \& Vigne 2003). This bone fragment showed no traces of shaping or use, but given that half metapodials of small ruminants were frequently used for tool fabrication during the Neolithic in north-western Eu- rope (e.g., Camps-Fabrer 1990b), it is possible that it is part of a broken implement, such as the awl made on a sheep metatarsal described below (see below "Neolithic bone artefacts"; Fig. 4B).

\section{ANALYSIS OF THE BONE INDUSTRY}

\section{UNDATED BONE ARTEFACT}

The sole conspicuous piece of ornamentation found in the rock-shelter is an upper left canine of a red deer, the root of which had been pierced in the middle, on the lingualvestibular plane (Fig. 5A). This object was found during the late-20th century excavations, within the rubble of the older excavations, which had disturbed the Mesolithic collective burial. Therefore, even if this find cannot be securely linked to any context, it seems reasonable to assume that it was originally associated with this Mesolithic collective burial, as suggested earlier by Cauwe (1997).

The tooth comes from an adult hind 6-10 years of age, based on morphometric criteria formulated by D'Errico \& Vanhaeren (2002). The root was pierced through rotation with a pointed lithic tool, both from the lingual and the vestibular sides, as indicates a small bulge visible halfway inside the perforation (Fig. 5B). Almost all the enamel has disappeared from the crown surface, with the exception of a tiny portion remaining near the tip (Fig. 5C). This may have resulted from natural wear occurring during the use of the object as an ornament or from intentional removal of the enamel, which has been shown through use-wear analysis on Palaeolithic examples (D’Errico \& Rigaud 2011). No striations were recorded on the surface of the Abri des Autours tooth, but they may have been obliterated during the wearing of the object. A light polish and some minute flakes are present at the periphery of the perforation, at the basal portion of the perforation (Fig. 5B). They suggest, together with the strong polish of the crown surface, that the tooth was used as a pendant, freely suspended on a string rather than sewn onto an item of clothing. The base of the root also shows slight polish. Nonetheless, since there is no pronounced wear on the periphery of the perforation, the diameter of the thread is thought to have been close in size to that of the perforation.

Some ancient fibres were identified from inside the perforation, but their number is very low. Therefore, it was not possible to determine whether the fibres originated from the string from which the ornament was suspended, or whether they are contaminations from the burial content, its environment, or handling after excavation. For this reason, no further residue analysis was attempted on the other bone artefacts from the site.

Perforated red deer canines were used all over Europe as ornaments starting in the Upper Palaeolithic (Châtelperronian) and continuing until at least the Bronze Age.

\section{NeOLITHIC BONE ARTEFACTS}

As mentioned above, several artefacts were discovered in association with the human bones of the Neolithic collective burial, six of which represent tools made of animal remains. 


\section{Awl-sheep metatarsal}

One half of a sheep or goat metatarsal has been transformed into an awl (Fig. 4B). The unfused distal epiphysis indicates that it comes from an immature individual less than two-anda-half years old (Popkin et al. 2012). Striations indicate that the bone was first carved longitudinally with a stone tool in the middle of the diaphysis in order to split it into two halves. A point was then created on one of those halves, roughly halfway the diaphysis. This was done through abrasion, as indicated by the strong, oblique striations still preserved on the surface of the medullary cavity. A strong polish developed on the proximal one third of the point, which was the working end of the tool. The less developed use wear at the base of the tool probably results from it being hand-held. Produced from the Upper Palaeolithic period onward, these kinds of tool made of half metapodials of small ruminants became widespread all over Europe during the Neolithic. From then on, sheep and goat were preferred over wild species as suppliers of the raw material (Camps-Fabrer 1990b).

\section{Pointed ribs - large bovids}

Two segments of cattle or aurochs Bos primigenius Bojanus, 1827 rib shafts had been modified, both in a similar way. The first rib is oval in cross-section and reduced in width (Fig. 6). On the sternal two thirds of the rib segment, approximately, the lateral surface has been eliminated, leaving only the medial surface. In some cases, this kind of preparation was done by splitting the bone using indirect percussion (Sidéra 2004). The cranial and the caudal sides have been thinned down and cut at an angle in order to create a large point at the sternal extremity. A polish has developed on the sternal half of the tool, which indicates that this was the working end of the tool. No other striations than those made during the shaping of this object were recorded on the vertebral half (Fig. 6D), which was probably used as a handle. The medullary bone has almost completely disappeared from the exposed surface of the internal face of the internal blade, which suggests that this surface was in contact with the material on which the tool was used. The medullary bone may have been removed intentionally prior to utilization of the item or it may have worn out through the use of the tool, before the surface became polished during use. A strong, smooth polish has developed on the tip, a location where fine, parallel striations mostly oriented perpendicularly to the point edge are also visible (Fig. 6B, C). This indicates that the motion imparted to the object was perpendicular to its axis.

The second segment rib is more robust, larger in width than the first one but flatter (Fig. 4F) and less curved latero-medially. It underwent a similar kind of preparation. The cranial and the caudal sides have been cut at an angle in order to create a point, which is more acute but blunt. Latero-medially, the rib has been thinned down through abrasion or scraping of the lateral surface on the ventral one third, where deep longitudinal striations related to the shaping process are preserved. In contrast to the other rib, the lateral surface is preserved closer to the point, protecting the medullary bone from use-wear. This thinner part of the lateral surface broke either before or after being deposited and is now missing. The remaining part of the lateral surface is damaged, and a large portion now comes off. No striations are visible on the dorsal two thirds of the rib segment, which was used as a handle, contrary to the ventral one third, which constitutes the active part.

Ribs of large herbivores have been shaped and fashioned into points since the Palaeolithic (Camps-Fabrer 1990c). For the Neolithic, specimens similar to the narrowest rib from the Abri des Autours (Fig. 6) are known from the Belgian site of Spiennes, where they have been interpreted as ceramic smoothers (Loë 1928), and from sites in France, e.g., Mairy 'Les Hautes Chanvrières' (Michelsberg; Sidéra 2004) and Escalles 'Mont d'Hubert' (Middle Neolithic II; Y. Maigrot pers. comm.). In the case of Mairy, the rib was used on fresh hide (Maigrot 1997). The use-wear observed on the ribs from the Abri des Autours is consistent with their use as hide processing tool, but further analysis is required to confirm this observation.

Ribs from deer or cattle fashioned into points in the same way as the more robust rib from the Abri des Autours (Fig. 4F) have been discovered at other sites, sometimes bound together to form composite objects. Such exceptionally preserved composite objects have been found in several Neolithic lacustrine settlements in Switzerland, e.g., in Nidau 'BKW' (Hafner \& Suter 2004) and Twann (Schibler 1981). Those artefacts have been interpreted as combs designed for the working of vegetal fibres, probably scotching or carding, although their exact use is still debated (Médard 2008).

\section{Needle - wild boarldomestic pig fibula}

A left fibula from a wild boar or a pig has been modified to create a kind of needle (Fig. 7). Because the distal epiphysis is unfused, it must come from an animal younger than two or three years of age (Zeder et al. 2015). Approximately the distal two thirds of the initial bone are preserved. The proximal part of the diaphysis has been shaped to form a point by cutting the plantar side of the diaphysis diagonally and by thinning down the lateral and medial sides. The tip of the point later broke off, perhaps during use. Although traces of the manufacturing process have been blurred by the development of a strong polish resulting from use over half of the length from the tip of the tool, it seems reasonable to assume that shaping was done through abrasion. The distal epiphysis, the surface of which is porous because of the young age of the animal it comes from, has been pierced from the lateral side. The perforation is oblique with respect to the lateral surface, which may be explained by the fact that the proximal epiphysis was still in anatomical position when the bone was perforated. Indeed, the natural torsion of the bone would cause an inclination of the distal epiphysis in the dorsoplantar direction when the proximal epiphysis is pressed against a flat surface, which seems probable during the shaping process.

Use-wear analyses revealed a very smooth polish associated with fine and short striations on the tip of the tool (Fig. 7B), which appears to have resulted from the working of plant fibres. Further from the tip, only parallel striations are visible (Fig. 7C), while only a smooth polish is present around the middle of the tool (Fig. 7D).

This kind of point made on a suid fibula was produced from the Palaeolithic period to at least the Bronze Age. When suid bones are used, they frequently come from young animals, as it is the case with the specimen of the Abri des Autours. 
A
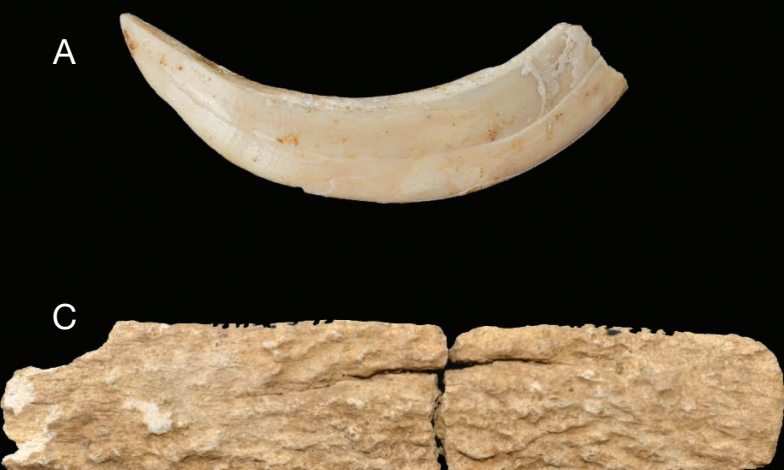

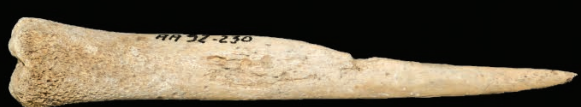

D

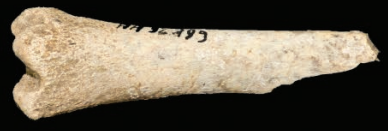

$\mathrm{E}$

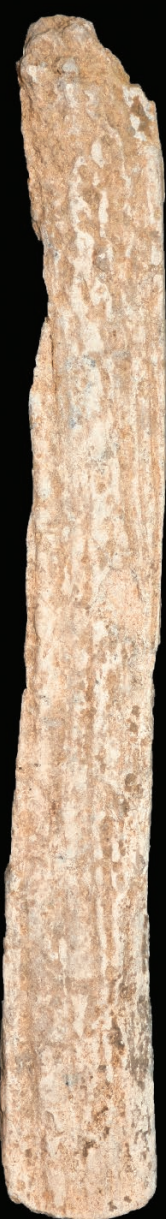

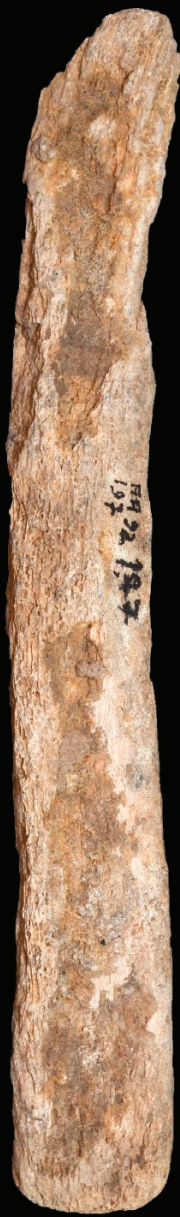

F

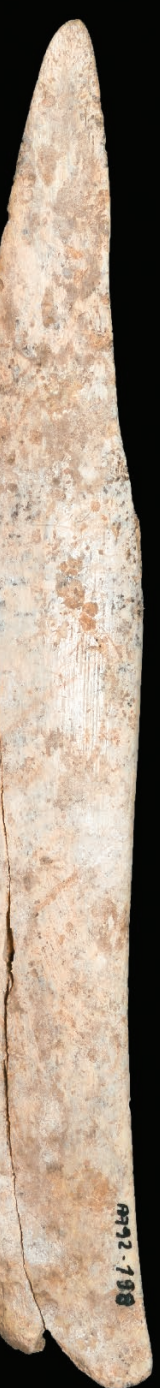

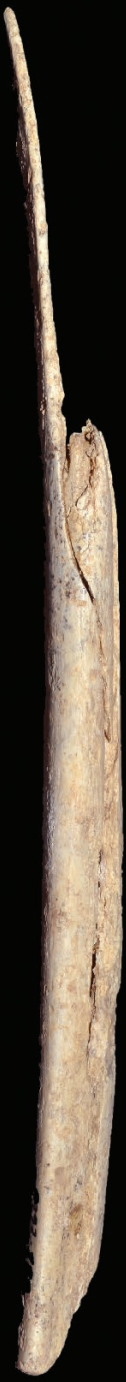

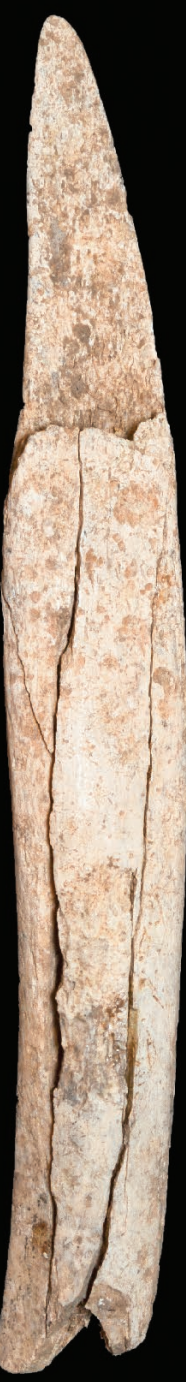

FIG. 4. - Some of the animal bones from the Neolithic collective burial of Abri des Autours: A, inferior left canine of a male suid; B, awl made of a sheep or goat metatarsal; C, E, rods made of red deer antler; $\mathbf{D}$, unmodified fragment of roe deer metatarsal; $\mathbf{F}$, rib of a large bovid fashioned into a point (from left to right: internal, lateral and external views). Scale bar: $5 \mathrm{~cm}$.

Concerning their spatial distribution, they seem to be more common in south-western Europe and in Switzerland than in the rest of Europe (Camps-Fabrer 1990a).
Red deer antler - rods

Two red deer antler beam fragments had been modified. One is approximately rectangular in shape and relatively long 


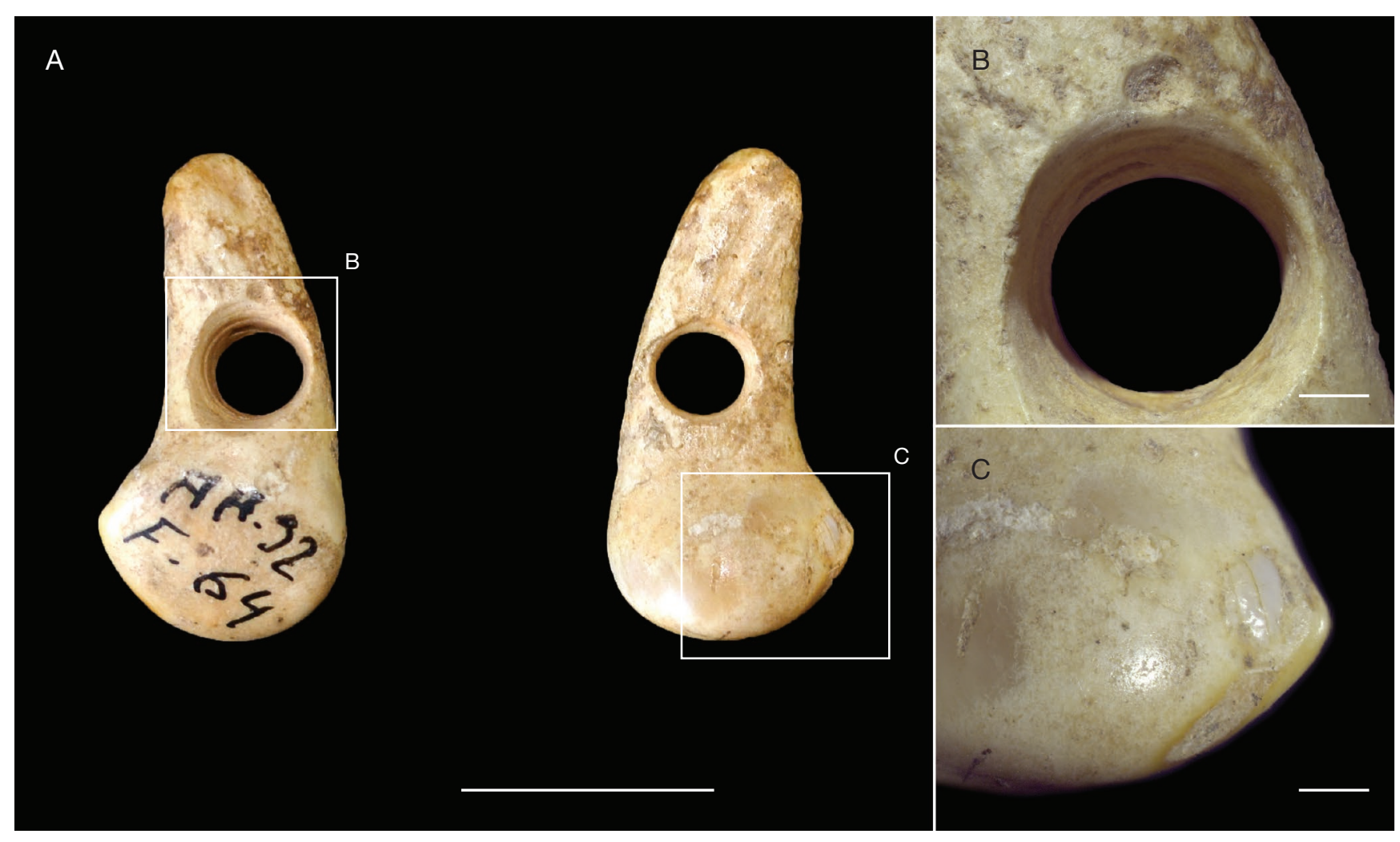

FIG. 5. - Undated female red deer upper left canine from Abri des Autours. A, general view; B, detail of perforation; C, detail of the crown with remaining traces of enamel (arrow). Scale bars: A, $10 \mathrm{~mm}$; B, C, $1 \mathrm{~mm}$.

and thick, with a flat, rectangular cross-section (Fig. 4E). One of its extremities is rounded, while the other is damaged (from use?). Based on the visible traces, it appears this antler fragment was separated from the rest of the beam by grooving with a stone tool. The rounded extremity presents traces of sawing from shaping, but no traces of use are visible. Consequently, this may not have been the working end of the tool, and its use as a handle cannot be excluded.

The other implement made of red deer antler is short, almost rectangular in shape, with a very flat, rectangular cross-section (Fig. 4C). One of the extremities is rounded, while the other is broken. The surface is eroded, and no traces of shaping or utilization are visible. Flat red deer antler rods are frequent in Europe from the Middle Neolithic through to the Bronze Age. The purpose of these objects is not yet clear, and different interpretations have been proposed, including retouching tools for flint knapping, smoothers for ceramic production and shuttles for weaving (Camps-Fabrer \& Ramseyer 1992). We note that this is also possible that similar-looking objects may have been used in different kinds of activities.

\section{DISCUSSION}

The first goal of the present analysis was to investigate possible associations of scattered animal remains with Mesolithic funeral or domestic activities. Animal bones were frequently deposited in Mesolithic graves. A review of 232 Mesolithic burial sites in Europe by Grünberg (2013) indicates that $42 \%$ of them yielded faunal remains directly associated with the human bodies. Animal bones were found to have been most often deposited in collective burials. Unmodified parts of mammals were recorded in $23 \%$ of the sites included in Grünberg's analysis. In the northern half of France, artefacts deposited in Mesolithic burials are rare and mostly comprise modified animal parts, such as necklaces made of pike Esox lucius Linnaeus, 1758 vertebrae; awls made of animal bone; deer and suid canines; perforated shells; or antler tools (Bosset \& Valentin 2013).

However, the zooarchaeological analysis performed here, in particular the detailed taphonomic study, demonstrates the significant heterogeneity of the faunal assemblage. Indeed, the animal species identified range from the Late Glacial to the medieval period, and the patina and surface preservation are variable. The high frequency of gnaw marks from carnivores suggests that most of the animal remains are intrusive and consist of portions of animal carcasses brought in by scavengers. Among the few bones displaying anthropogenic modifications, none can be attributed to the Mesolithic.

Apart from the Abri des Autours, seven Belgian caves in the Meuse Basin yielded Mesolithic burials (for summaries, see Cauwe 1997, 2001; Toussaint 2010). Archaeological material has sometimes been discovered in association with the human remains, but animal bones have been reported from only two other sites, both in what is today Belgium. These are the caves of Petit Ri, in the Malonne area of Namur, and Bois Laiterie, in the municipality of Profondeville. 


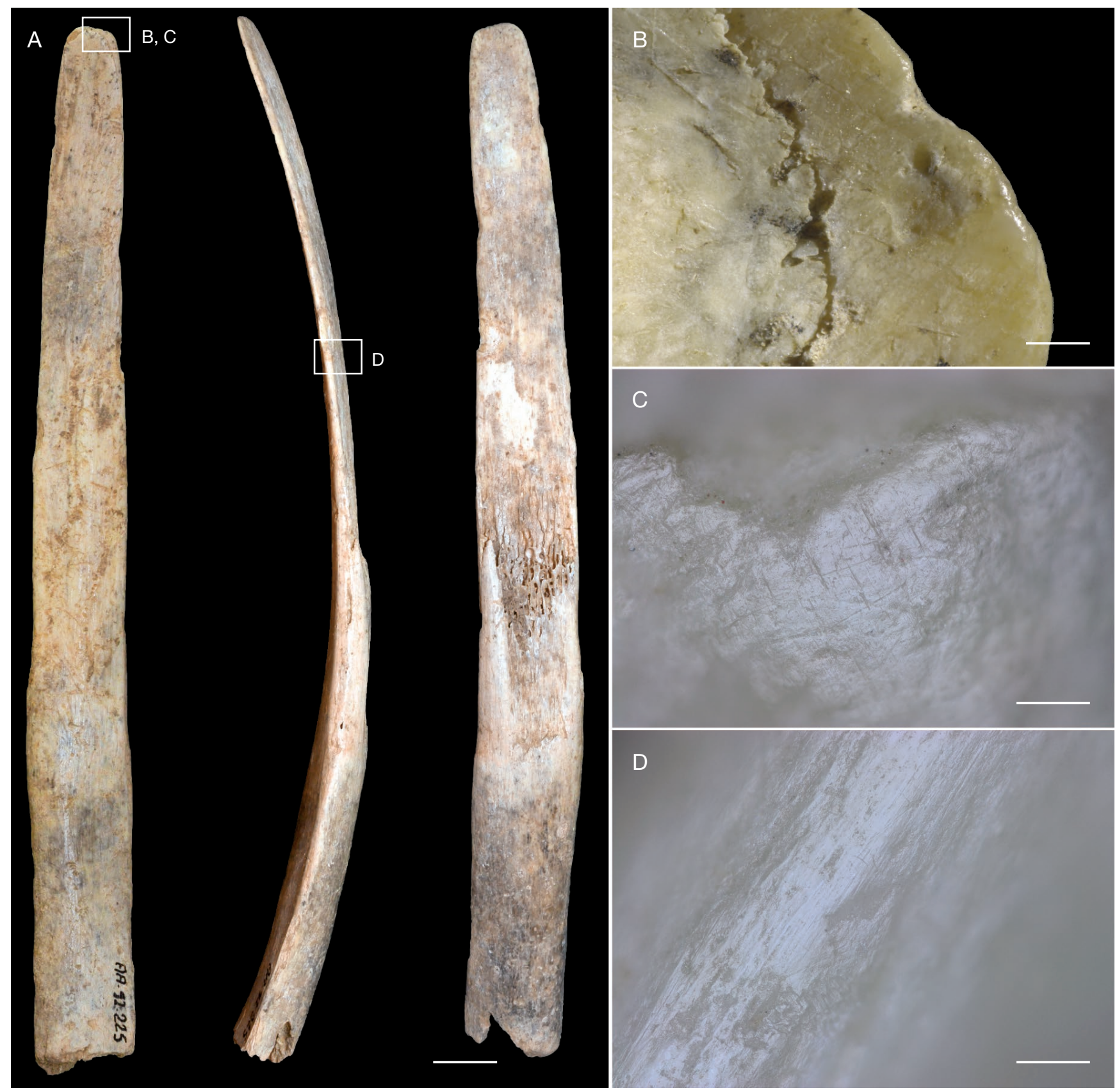

FIG. 6. - Pointed rib of a large bovid, from the Neolithic collective burial at Abri des Autours: A, general view (from left to right: internal, centre and external views); $\mathbf{B}$, detail of the tip (internal view) showing some polish; $\mathbf{C}$, detail of the tip (internal view) showing fine perpendicular striations; $\mathbf{D}$, detail of a lateral edge of the rib devoid of striations. Scale bars: A, $10 \mathrm{~mm}$; B, $500 \mu \mathrm{m}$; C, D, $100 \mu \mathrm{m}$.

The animal remains of Petit Ri cave were studied by J.-M. Cordy (1994). He also noted some heterogeneity within the faunal assemblage, illustrated by the variability in the fossilization processes and by the chronological attributions of the taxa identified. Two species were attributed to the Weichselian, namely, the cave hyena Crocuta crocuta spelaea (Goldfuss, 1823) and an unidentified horse species Equus sp., while the remaining species were attributed the more temperate climate of the Holocene period. However, if the horse species is the wild horse Equus ferus Boddaert, 1785, a Holocene age is also possible (see Sommer et al. 2011). Among the species attributed to the Holocene, some taxa, such as the domestic pig, are clearly more recent in age than the Mesolithic period. In contrast to Abri des Autours, at Petit Ri, cut marks made with stone tools were detected on wild boar bones, suggesting they could be Mesolithic in age. The spatial distribution of the bones was not recorded, but J.-M. Cordy (1994) indicates that the faunal remains were found in fairly close association with the human bones.

The fauna of Bois Laiterie was studied by A. Gautier (1997), who attributed the rabbit, badger Meles meles (Linnaeus, 1758), wild boar, domestic cat and domestic cattle remains to the 
Holocene, while he interpreted the other taxa as Pleistocene. Based on species history, only the badger and the wild boar could be Mesolithic in age. For the horse, which was identified and interpreted by A. Gautier (1997) as being Pleistocene in age, a Holocene age, again, cannot be excluded. No direct association with the Mesolithic burial could be established.

Similarly, no bone can be securely associated with Neolithic activity. The only potential exception is a humerus of a goat possibly broken by humans, which was discovered in the rubble of the old excavations.

The second goal of this study was to document the artefacts recovered in Abri des Autours. For the pendant made of a pierced tooth of a hind, the chronological attribution to the Mesolithic remains hypothetical in the absence of a direct association with the Mesolithic grave and/or radiocarbon dating. To date, no animal bones have been directly associated with Mesolithic burials in Belgium, and Abri des Autours follows this pattern.

In contrast, the artefacts associated with the Middle Neolithic collective burial are much more informative and allow for the documenting of Michelsberg funerary practices. The archaeological excavations clearly show their direct association with the human remains. However, due to the successive human interventions on the corpses, it is unclear whether the artefacts represent primary or later deposits. In any case, they do not seem to have been associated with one individual in particular. Similarly, even though men and women, adults and children were identified among the human remains, the offerings could not be correlated with either the sex or the age of the buried individuals.

Neolithic deposits of animal artefacts are recurrent in Europe. A review of 400 graves dating to the $4^{\text {th }}-3^{\text {rd }}$ millennia BC from the Paris Basin demonstrated that $55 \%$ of them had yielded animal offerings (Polloni et al. 2004). By contrast, Neolithic burials with associated fauna are scarce in Belgium. Apart from Abri des Autours, only three other caves, all situated on tributaries of the river Meuse, have yielded animal artefacts, all attributed to the Michelsberg: Trou de la Heid, in Comblain-auPont; Grand abri, in Ben-Ahin; Trou des Nots, in Salet (Fig. 1).

Another karstic site, Faucille cave, in Sclayn, yielded human remains dating to the Late Neolithic, together with some artefacts, including a pierced canine of a carnivore and an awl made of animal bone (K. Di Modica pers. comm.). The site is still being excavated, and detailed documentation is not yet available.

The site of Trou de la Heid is located along the river Ourthe, at about $60 \mathrm{~km}$ distance from Abri des Autours. A radiocarbon date on the human remains recovered from the Trou de la Heid indicates an age of 3380-3530 BC at 1 sigma (Lv-1586, $4650 \pm 60$ BP, Toussaint \& Becker 1994). The human remains, representing one adult and one child, were associated with several objects. They include 31 lithic implements, namely, perforators, scrapers, retouched blades and arrow points, as well as decorated pottery sherds and animal artefacts (Toussaint \& Becker 1994). The latter include six lower canines of (male) wild boar. Three of them have not been modified, but the other three have been artificially thinned down on their apical part. One of those thinned-down canines was then decorated with crossed lines. Another suid lower canine, probably coming from a female domestic pig, has been perforated at the root. One sheep metacarpus that has been sagitally cut in two but that displays no other modifications was also discovered, together with two left valves of the freshwater pearl mussel Margaritifera margaritifera (Linnaeus, 1758) that were pierced near the apex (Cordy et al. 1992; Toussaint \& Becker 1994).

The two other sites yielded fewer bone items. Grand abri is located along the river Solières, at a distance of ca $40 \mathrm{~km}$ from Abri des Autours. Several artefacts were discovered in association with human bones, specifically, Seine-Oise-Marne ceramic sherds and ornaments made of perforated teeth, including one human incisor, four wild boar incisors and two fox canines (Destexhe-Jamotte 1973). However, some uncertainty remains about the discovery context of this assemblage. Trou des Nots is located along the river Molignée and is only $c .10 \mathrm{~km}$ from Abri des Autours. Aside from human remains, it yielded an awl made of a large ruminant bone (Otte \& Evrard 1985).

Finally, the unmodified wild boar canine and the unworked, longitudinally split sheep metacarpus from Trou de la Heid are reminiscent of the suid canine and the roe deer metatarsal fragment associated with the Neolithic burial at Abri des Autours.

The association of ornaments and tools is frequent in the Chasséen and Michelsberg cultures, as exemplified by the collection from Trou de la Heid, which comprises mostly ornaments, but also tools. This is in contrast to Abri des Autours, where only tools were discovered. At both Abri des Autours and Trou de la Heid, bone artefacts were made out of bones of wild animal species. In the case of Abri des Autours, red deer, roe deer and probably wild boar were utilized, but the exact proportion of implements made of wild versus domestic species is hard to establish because the taxon of some of them could not be reliably identified. However, at least three of the deposited implements were made of wild taxa, including two made of red deer. The fact that most of the bone artefacts from Abri des Autours had been used before they were deposited is common for such offerings; unused objects are the exception (Polloni et al. 2004). In conclusion, the animal artefacts from Abri des Autours present several traits typically encountered in Michelsberg burials.

Future analysis of the material from Abri des Autours and other Belgian sites should focus on a more detailed micro-wear analysis of the Neolithic bone artefacts in order to clarify the exact utilization of these implements.

\section{CONCLUSIONS}

Archaeological and anthropological studies associated with radiocarbon dating have indicated that the Abri des Autours rock-shelter was used several times for human burials, during both the Mesolithic and the Neolithic periods. The zooarchaeological analysis of the bones recovered some twenty years ago at Abri des Autours provides more information about the diachronic use of the site.

The zooarchaeological analysis shows that most of the animal remains are intrusive and result from either casual deaths of species using the site for shelter or accumulations produced by carnivores. A few bones are burned or display butchery marks, but 

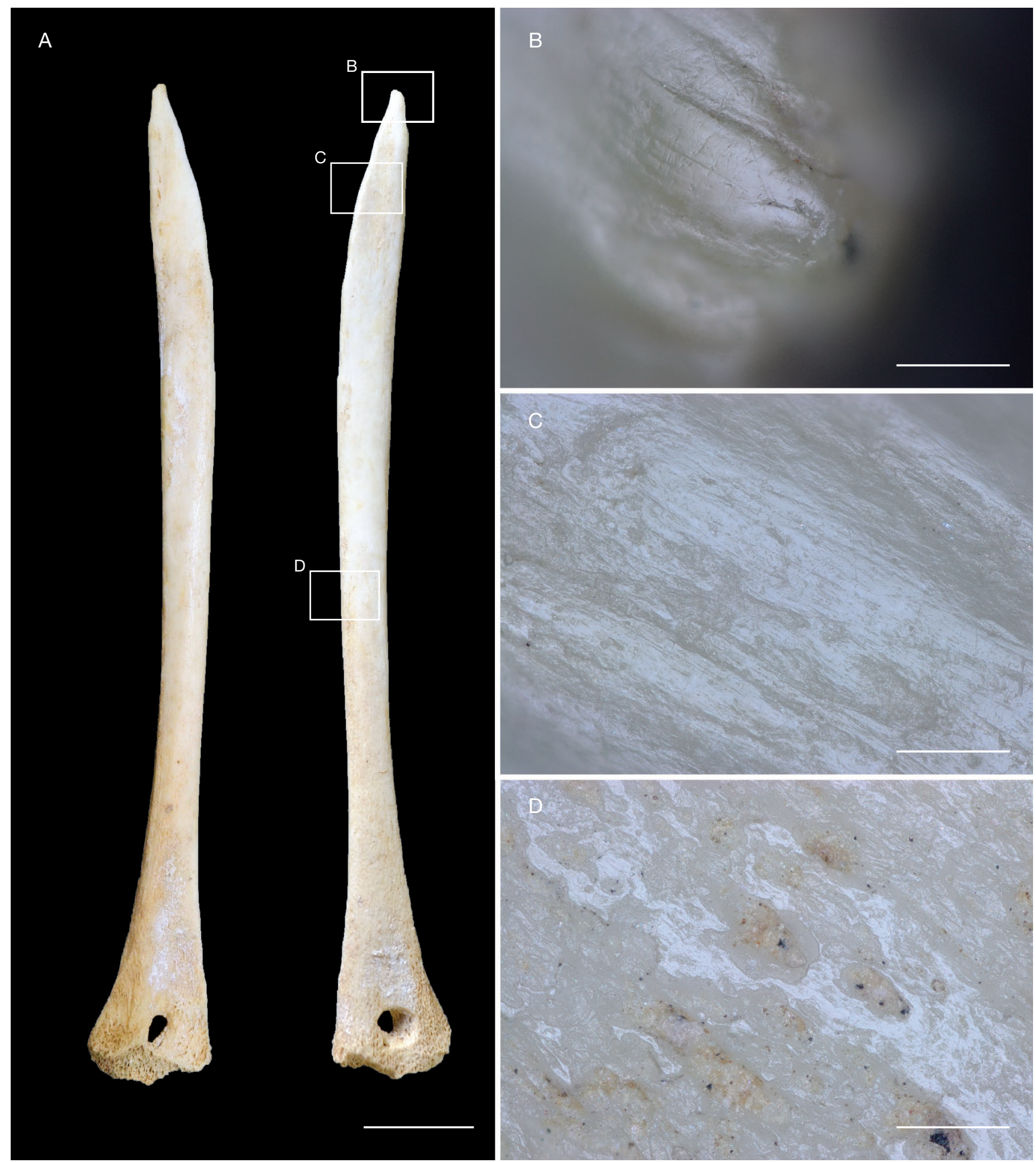

FIG. 7. - Needle made of a suid left fibula, from the Neolithic collective burial at Abri des Autours: A, general view; B, detail of the tip showing a smooth polish associated with fine and short striations; $\mathbf{C}$, detail of the posterior edge near the point, showing fine parallel striations; $\mathbf{D}$, detail of the posterior edge at the midpoint of the tool, showing smooth polish. Scale bars: A, $10 \mathrm{~mm}$; B, C, D, $150 \mu \mathrm{m}$.

none of the marks are Mesolithic in age, confirming the absence of domestic activity in Abri des Autours during the Mesolithic and the more general absence of faunal material resulting from human activities in Mesolithic cave burials in Belgium. One bone may possibly reflect butchery practices that could be of
Neolithic age or probably younger, given the presence of other bones with either burning or cut marks made with metal tools.

In contrast, there is a clear association between humanly modified fauna material and the Neolithic collective burial. Two elements are devoid of human modifications, but six 
had been modified into tools. These tools appear to have been manufactured from the remains of both domestic and wild animal species, and a preliminary use-wear analysis has indicated that they were used before their deposition, which are two traits commonly documented in other Michelsberg burials from Europe.

\section{Acknowledgements}

We want to thank Carol Lentfer (TraceoLab, ULg), who kindly assisted in the residue analysis of the ornament; Mietje Germonpré (RBINS), who confirmed the identification of arctic fox; and Evelyne Fiers, who conducted a preliminary analysis of the faunal collection in 2003. We also thank Yolaine Maigrot (CNRS, UMR 8215-Trajectoires), for her suggestions about some of the micro-wear observed on the material presented here. Finally, we are grateful to Wim Van Neer for his valuable comments on a previous draft of the manuscript and to two anonymous reviewers for their helpful suggestions, which helped improve this paper.

\section{REFERENCES}

Barge-Mahieu H. 1991. - Fiche défenses de suidés (1.4.), in CAMps-Fabrer H. (ed.), Objets de parure. Fiches typologiques de l'industrie osseuse préhistorique, cahier IV. Publications de 1’Université de Provence, Aix-en-Provence: 1-6.

Bocherens H., Polet C. \& Toussaint M. 2007. — Palaeodiet of Mesolithic and Neolithic populations of Meuse Basin (Belgium): evidence from stable isotopes. Journal of Archaeological Science 34 (1): 10-27. https://doi.org/10.1016/j.jas.2006.03.009

Bosset G. \& VAlENTin F. 2013. - Mesolithic burial practices in the northern half of France: isolated burials and their spatial organisation, in VAlEnTin B., SOUfF B., DucrocQ T., FAGNART J.-P., SÉara F. \& Verjux C. (eds), Palethnographie du Mésolithique. Recherches sur les habitats de plein air entre Loire et Neckar. Actes de la table ronde internationale de Paris, 26 et 27 novembre 2010. Société préhistorique française, Paris: 207-216.

CAMPS-FABRER H. 1990a. - Fiche poinçon pris sur fibula entière de suidé ou de petit mammifere (4), in CAMPS-FABRER H., RAMSEYER D. \& STORDEuR D. (eds), Poinçons, pointes, poignards, aiguilles. Fiches typologiques de l'industrie osseuse préhistorique, cahier III. Publications de l'Université de Provence, Aix-en-Provence: 1-5.

CAMps-Fabrer H. 1990b. - Fiche poinçon sur métapode fendu de petit ruminant (8), in CAMPS-FABRER H., RAMSEYER D. \& STORDEur D. (eds), Poinçons, pointes, poignards, aiguilles. Fiches typologiques de l'industrie osseuse préhistorique, cahier III. Publications de 1'Université de Provence, Aix-en-Provence: 1-16.

CAMPS-FABRER H. 1990c. - Fiche pointe plate sur côte (11), in Camps-Fabrer H., Ramseyer D. \& Stordeur D. (eds), Poinçons, pointes, poignards, aiguilles. Fiches typologiques de l'industrie osseuse préhistorique, cahier III. Publications de l'Université de Provence, Aix-en-Provence: 1-10.

CAMPS-FABRER H. \& RAMSEYER D. 1992. — Fiche baguette simple en bois de cerf (2.2), in Barge-Mahieu H., CAMps-Fabrer H., Feruglio V. \& Peltier A. (eds), Bâtons percés, baguettes. Fiches typologiques de l'industrie osseuse préhistorique, cahier V. Publications de 1'Université de Provence, Aix-en-Provence: 85-93.

Cauwe N. 1994. - De l'individuel au collectif: les sépultures de l'abri des Autours à Dinant (Namur). Notae Praehistoricae 13: 101-106.

CAUWE N. 1995. - Chronologie des sépultures de l'abri des Autours à Anseremme-Dinant. Notae Praehistoricae 15: 51-60.
CAUWE N. 1997. - Curriculum mortis. Essai sur les origines des sépultures collectives de la préhistoire occidentale. Thèse de doctorat en Philosophie et Lettres, Université de Liège, 736 p.

CAUWE N. 2001. - Skeletons in motion, ancestors in action: Early Mesolithic collective tombs in southern Belgium. Cambridge Archaeological Journal 11 (2): 147-163. https://doi.org/10.1017/ S0959774301000087

CauWe N. 2004. - Les sépultures collectives néolithiques en grotte du Bassin mosan. Bilan documentaire. Anthropologica et Praehistorica 115: 217-224.

CORDY J.-M. 1994. — Étude de la faune de la Grotte du Petit Ri à Malonne. Anthropologica et Praehistorica 105: 87-91.

CORDY J.-M. \& STASSART M. 1984. — La faune omalienne de la place Saint-Lambert à Liège, in OTTE M. (ed.), Les fouilles de la place Saint-Lambert à Liège 1. Université de Liège, Liège: 235237. (Coll. ERAUL; 18).

Cordy J.-M., Toussaint M. \& BeCKer A. 1992. - Les objets zooarchéologiques du trou de la Heid à Comblain-au-Pont (province de Liège, Belgique). Bulletin des chercheurs de la Wallonie 32: 31-41.

D'ERrico F. \& VANHAEREN M. 2002. - Criteria for identifying red deer (Cervus elaphus) age and sex from their canines. Application to the study of Upper Palaeolithic and Mesolithic ornaments. Journal of Archaeological Science 29 (2): 211-232. https://doi. org/10.1006/jasc.2001.0687

D'ERRICO F. \& Rigaud S. 2011. — Crache perforée dans le Gravettien du sire (Mirefleurs, Puy-de-Dôme). Paléo 22: 301-310.

DesteXhe-JamotTe J. 1973. - Le grand abri sous roche de BenAhin, vallée de la Solières, province de Liège. Bulletin des Chercheurs de la Wallonie 22: 213-258.

ERVynCK A., VAN NEER W. \& LENTACKer A. 1999. — Introduction and extinction of wild animal species in historical times: the evidence from Belgium, in BENECKE N. (ed.), The Holocene History of the European Vertebrate Fauna. Modern Aspects of Research. Marie Leidorf, Rahden: 399-407.

GAUTIER A. 1987. - Taphonomic groups, how and why? Archaeozoologica 12: 47-52.

GAUTIER A. 1997. - The macromammal remains of la Grotte du Bois Laiterie, in OTtE M. \& Strauss L. G. (eds), La grotte du Bois Laiterie. Recolonisation magdalénienne de la Belgique. Presses universitaires de Liège, Liège: 177-196. (Coll. ERAUL; 80).

Germonpré M., LÁzNičKová-Galetová M. \& Sablin M. V. 2012. - Palaeolithic dog skulls at the Gravettian Předmostí site, the Czech Republic. Journal of Archaeological Science 39 (1): 184-202. https://doi.org/10.1016/j.jas.2011.09.022

GERMONPRÉ M. \& SABLIN M. V. 2004. - Systematics and osteometry of Late Glacial foxes from Belgium. Bulletin de l'Institut royal des Sciences naturelles de Belgique, Sciences de la Terre 74 : 175-188.

GinsberG J. R. \& MacDonald D. W. 1990. — Foxes, Wolves, Jackals, and Dogs. An Action Plan for the Conservation of Canids. IUCN/SSC Canid Specialist Group, Gland, 123 p.

GREENFIELD H. J. 2006. - Slicing cut marks on animal bones: diagnostics for identifying stone tool type and raw material. Journal of Field Archaeology 31: 147-163. https://doi. org/10.1179/009346906791071972

GRÜNBERG J. M. 2013. - Animals in Mesolithic burials in Europe. Anthropozoologica 48 (2): 231-253. https://doi.org/10.5252/ az2013n2a3

HaCHEM L. 2001. — La faune du village blicquien de Vaux-etBorset, in Burnez-LanotTe L., Caspar J.-P. \& CONSTANTIN C., Rapports chronologiques et culturels entre Rubané et Groupe de Blicquy à Vaux-et-Borset (Hesbaye, Belgique). Bulletin de la Société préhistorique française 98 (1): 74-76.

HAFNer A. \& SuTER J. P. 2004. - 5000 Jahre Aufgetaucht, 19842004. Archäologischer Dienst des Kantons Bern, Bern, 56 p.

Jacob J.-P., Dehem C., Burnel A., Dambiermont J.-L., Fasol M., Kinet T., VAn Der Elst D. \& PAQUet J.-Y. 2010. - Atlas des oiseaux nicheurs de Wallonie 2001-2007. Aves, Gembloux, 524 p. 
Larson G., Karlsson E. K., Perri A., Webster M. T., Ho S. Y. W., Peters J., Stahl P. W., Piper P. J., Lingaas F., Fredholm M., Comstock K. E., Modiano J. F., Schelling C., Agoulnik A. I., Leegwater P. A., Dobney K., Vigne J.-D., Vilà C., ANDERSSON L. \& LindBLAD-TOH K. 2012. — Rethinking dog domestication by integrating genetics, archeology, and biogeography. Proceedings of the National Academy of Sciences 109 (23): 8878-8883. https://doi.org/10.1073/pnas.1203005109

LOË A. DE 1928. - Belgique ancienne: catalogue descriptif et raisonné. 1. Les Âges de la Pierre. Bruxelles, Vromant \& Co., 261 p.

MAIGROT Y. 1997. - Tracéologie des outils tranchants en os des Ve et IVe millénaires av. J.-C. en Bassin parisien: essai méthodologique et application. Bulletin de la Société préhistorique française 94 (2): 198-216. https://doi.org/10.3406/bspf.1997.10878

MÉDARD F. 2008. - L'acquisition des matières textiles d'origine végétale en préhistoire: l'apport des données expérimentales et ethnographiques. Les nouvelles de l'archéologie 114: 23-28. https:// doi.org/10.4000/nda.602

MONCHOT H. \& GENDRON D. 2010. — Disentangling long bones of foxes (Vulpes vulpes and Alopex lagopus) from arctic archaeological sites. Journal of Archaeological Science 37 (4): 799-806. https://doi.org/10.1016/j.jas.2009.11.009

OTTE M. \& EvRARD J.-M. 1985. — Salet, sépulture du Néolithique moyen. Helinium 25: 157-164.

OUTRAM A. K. 2002. - Bone fracture and within-bone nutrients: an experimentally based method for investigating levels of marrow extraction, in Miracle P. \& Milner N. (eds), Consuming Passions and Patterns of Consumption. McDonald Institute for Archaeological Research, Cambridge: 51-64. http://hdl.handle. net/10036/30952

Polet C. \& CAUWE N. 2007. —Étude anthropologique des sépultures préhistoriques de l'abri des Autours (Province de Namur, Belgique). Anthropologica et Praehistorica 118: 71-110.

POlet C. \& Dutour O. 2007. — Étude paléopathologique des squelettes de l'Abri des Autours (Province de Namur, Belgique). Anthropologica et Praehistorica 118: 127-160.

Polloni A., MAÏTENA S. \& SidÉra I. 2004. - Structure du mobilier funéraire en os, bois de cerf, dents et coquillages à la fin du $4^{\mathrm{e}}$ et au 3 e millénaire en Bassin parisien. Actes de la journée d'études SRBAP-SPF, 8 mars 2003, Lille. Anthropologica et Praehistorica 115: 179-195.

Popkin P. R. W., Baker P., Worley F., Payne S. \& Hammon A. 2012. - The Sheep Project (1): determining skeletal growth, timing of epiphyseal fusion and morphometric variation in unimproved Shetland sheep of known age, sex, castration status and nutrition. Journal of Archaeological Science 39 (6): 1775-1792.
Ruwet J. C. 1988. - Tétras lyre, Tetrao tetrix, in Devillers P. Roggeman W., Tricot J., Del Marmol P., KerWijn C., JaCOB J.-P. \& ANSELIN A. (eds), Atlas des oiseaux nicheurs de Belgique. Royal Belgian Institute for Natural Sciences, Bruxelles: 94-96.

SCHIBLER J. 1981. - Typologische Untersuchungen der cortaillodzeitlichen Knochenartefakte. Staatlicher Lehrmittelverlag, Bern, 135 p. (Coll. Die neolithischen Ufersiedlungen von Twann; 17).

SIDÉRA I. 1997. - Le mobilier en matières dures animales en milieu funéraire Cerny: symbolisme et socio-économie, in CONSTANTin C., Mordant D. \& Simonin D. (eds), La Culture de Cerny, Nouvelle économie, nouvelle société au Néolithique. Association pour la promotion des recherches archéologiques en Île-de-France, Nemours: 499-513.

SidÉRA I. 2000. - Animaux domestiques, bêtes sauvages et objets en matières animales du Rubané au Michelsberg: de l'économie aux symboles, des techniques à la culture. Gallia Préhistoire 42: 107-194.

SidÉRA I. 2004. - Fiche exploitation de l'os au Néolithique dans les Bassin parisien et rhénan, in RAMSEYER D. (ed.), Matières et techniques, Industrie de l'os préhistorique, cahier XI. Publications de l'Université de Provence, Aix-en-Provence: 163-171.

SOMMER R. \& BENECKE N. 2005. - Late-Pleistocene and early Holocene history of the canid fauna of Europe (Canidae). Mammalian Biology-Zeitschrift für Säugetierkunde 70 (4): 227-241. https://doi.org/10.1016/j.mambio.2004.12.001

SOMMER R. S., BENECKE N., LÕUgas L., Nelle O. \& SCHMÖlCKE U. 2011. - Holocene survival of the wild horse in Europe: a matter of open landscape? Journal of Quaternary Science 26 (8): 805-812.

Tomé C. \& Vigne J.-D. 2003. - Roe deer (Capreolus capreolus) age at death estimates: new methods and modern reference data for tooth eruption and wear, and for epiphyseal fusion. Archaeofauna 12: 157-173.

TOUSSAINT M. 2010. — Les sépultures mésolithiques du bassin mosan wallon: où en est la recherche en 2010? Bulletin des Chercheurs de la Wallonie Hors-série 2: 69-86.

TOUSSAINT M. \& BECKER A. 1994. - Une sépulture du Michelsberg: Le trou de la Heid à Comblain-au-Pont (Province de Liège, Belgique). Bulletin de la Société préhistorique française 91 (1):77-84.

VON DEN DRIESCH A. 1976. - A Guide to the Measurement of Animal Bones from Archaeological Sites. Peabody Museum Press, Harvard, 148 p. (Coll. Peabody Museum Bulletin; 1).

Zeder M. A., Lemoine X. \& Payne S. 2015. - A new system for computing long-bone fusion age profiles in Sus scrofa. Journal of Archaeological Science 55: 135-150. https://doi.org/10.1016/j. jas.2014.12.017 
